\title{
Science ahead of the law
}

\section{Washington}

LAST week, a judge in a Tennessee courtroom was asked to decide if seven frozen human embryos were just 'property' and could be disposed of in the same way as other commonly-held goods in a divorce case, or should be considered as 'human life' with rights of their own. In Missouri, another judge is about to consider whether the controversial Missouri act restricting abortions really gives full rights to a fetus. If so, the judge may have to find a way to set free a fetus that a pregnant prison inmate claims is imprisoned illegally.

The Tennessee case involves a couple who are suing for divorce after nine years of unsuccesful attempts to produce a child. Among their 'jointly-owned property' are seven fertilized eggs (pre-embryos), which are in frozen storage. The eggs were removed from the wife and fertilized in vitro with the husband's sperm.

The husband argues that he has a right not to become a father. In his divorce petition, he asks that the court prevent his wife from implanting the eggs. His lawyer maintains that the seven embryos have no human characteristics beyond bearing human genetic material. They are less than 14 days from the time of conception, and are simply a small number of undifferentiated cells. The husband asks that the embryos be kept frozen indefinitely.

The lawyer for the wife argues that the embryos are human life and should be treated as 'children'. Custody over them should be granted to her wife and she should be allowed to implant them in order to become pregnant.

Pre-embryos are often frozen as a part of the effort to obtain a pregnancy through in vitro fertilization. Many eggs are usually removed from the potential mother's ovaries at one time and, after fertilization, they are allowed to advance to the eight-cell stage before some are selected for implantation. Any 'spare embryos' left over may be frozen so that they can be used again if no pregnancy has occurred.

There are continuing arguments over whether those spare embryos can be donated to women who either cannot produce eggs, or who have genetic deficiencies that make it inadvisable that they should do so. The fiercest disputes are over whether pre-embryos can discarded or used in research - eleven US states have banned research on human embryos.

The Tennessee case is the first time these issues have come up in a divorce proceedings. The lawyer for the wife opened the case by stressing that the central issue is "where life begins". He asked that the pre-embryos be labelled "preborn children". Jerome Lejeune, a French researcher who discovered the cause of Down's syndrome, agreed. He testified that pre-embryos are human life and referred to them as "tiny human beings". But John A. Robertson, a law professor from the University of Texas, argued that although the pre-embryo deserved a special respect as a potential person it should not be granted the same rights as a person.

The Judge is expected to rule on the case in $\mathbf{3 0}$ days time. It is the first ruling of biological importance to come out of a Tennessee courtroom since the famous Scopes trial on evolution.

In Missouri, it is the apparent success of the anti-abortion lobby in persuading the state to incorporate into law the declaration that "life begins at conception" and that unborn children have "all the rights, privileges and immunities available to other persons..." that is causing new ethical difficulties. The controversial act survived Supreme Court scrutiny earlier this year and reopened the national battle over the right to an abortion (see Nature 340, $83 ; 13$ July 1989 ) .

The new act has permitted an inmate of a Missouri prison to file a lawsuit against the state for illegally imprisoning her fetus. The lawyer for the woman argues that as the act has granted 'personhood' to the fetus, it cannot be sent to prison except as a punishment for a crime.

Alun Anderson

\section{Moons and rings for Neptune \\ Washington}

VOYAGER 2, closing in on its 25 August rendezvous with Neptune, has spotted three more previously unknown satellites and has confirmed the existence of partial rings, or rings arcs, around the giant planet. The three new moons all measure about $100 \mathrm{~km}$ across and, like the first satellite detected by Voyager (Nature 340, $86 ; 1989$ ), have roughly circular equatorial orbits, with radii ranging from 50,000 to $75,000 \mathrm{~km}$.

The existence of partial rings around Neptune had been inferred by astronomers who had seen unexpected occultations of stars passing behind the planet. Voyager's new photographs, received at the Jet Propulsion Laboratory in Pasadena, California, on August 11, show arcs of material apparently associated with two of the newly found moons: one arc lies just outside the innermost moon, $1989 \mathrm{~N} 4$, and the other lags behind $1989 \mathrm{~N} 3$, the next moon out, by about one quarter of an orbit. The arcs are thought to consist of small particies of debris, 'shepherded' by the gravitational influence of the nearby moons.

David Lindley

- The Space Shuttle Columbia landed at Edwards Air Force Base in California last Sunday after successfully completing a five-day secret defence mission. The flight restores the shuttle fleet to its complement of three orbiters. Columbia is the oldest of the shuttles and first flew in 1981.

\section{COLD FUSION}

\section{Utah backs new centre with $\$ 5$ million}

\section{Washington}

THE state government of Utah has decided to support research into cold fusion, despite growing apathy elsewhere, by spending $\$ 5$ million to establish the National Cold Fusion Institute at the University of Utah in Salt Lake City. The money was put aside when news of the claimed discovery by Stanley Pons and Martin Fleischmann first emerged (Nature 338, 447; 1989) but although some $\$ 500,000$ has been spent on legal fees and the filing of patents, the remainder had been kept back pending scientific confirmation of the reality of the phenomenon.

But last week, confirmation or not, an advisory panel to the state legislature voted by seven to one to release the money. The physicist on the panel, Wilford Hansen of Utah State University, abstained.

The $\$ 4.5$ million will be used over the next two years to establish a laboratory in an already existing building on the research park site of the University of Utah. As many as 40 people may be hired, and senior staff of the National Cold Fusion Institute will be faculty members of the University. For the time being, Hugo Rossi, a professor of mathematics at the University of Utah, will act as director of the Institute, but a search for a permanent director has begun.

Whether the new Institute will have anything of substance to conduct research on is still an undecided matter. Outside Utah, few other claims of significant heat production from palladium electrodes in heavy water are being heard, and a number of negative results have now been published. (On page 525 of this issue of Nature, Nathan Lewis and his colleagues give an account of the failure of a series of experiments at the California Institute of Technology to unearth anything out of the ordinary.)

Nevertheless, the University of Utah has seven cold fusion patents under consideration, and has two more applications almost ready to be submitted. A spokesperson for the university said that they had received no word yet on their applications, and that it might well be two or three years before a decision was made. The backlog at the General Patent Office in Washington is such that ten months can easily elapse before a submitted application is even examined.

David Lindley 